\title{
In vitro study on the interaction of ketotifen fumarate with anhydrous theophylline
}

\author{
Mohammed Aktar Sayeed", Razibul Habib,", Mominur Rahman', Hasan Al Banna1, Sohel Rana ${ }^{3}$ \\ ${ }^{1}$ Department of Pharmacy, International Islamic University Chittagong, Bangladesh, ${ }^{2}$ Department of Pharmacy, East West \\ University, Dhaka, Bangladesh, ${ }^{3}$ Department of Pharmacy, Jahangirnagar University, Savar, Dhaka, Bangladesh
}

\begin{abstract}
The purpose of the present study was to investigate the interaction between ketotifen fumarate and anhydrous theophylline in aqueous media of various $\mathrm{pH}$ (1.2 and 6.8). Using Job's continuous-variation analysis and Ardon's spectrophotomeric measurement methods, the values of the stability constants of theophylline with ketotifen were determined at a fixed temperature $\left(37^{\circ} \mathrm{C}\right)$ at various $\mathrm{pH}$. The stability constants, ranging between 5.66 and 9.92, were derived from Ardon's plot, indicating that comparatively stable complexes had formed as a result of an interaction between the drugs. However, following the interaction of theophylline with ketotifen, stability constants were $<1$ at gastric $\mathrm{pH}$ (1.2) and intestinal $\mathrm{pH}$ (6.8). Concurrent administration of ketotifen and theophylline could result in the formation of a stable complex and this is likely to reduce the therapeutic activities of both drugs.
\end{abstract}

Uniterms: Stability constant. Job’s method. Ardon's method. Ketotifen. Theophylline.

O objetivo do presente estudo foi investigar a interação entre o fumarato de cetotifeno e a teofilina anidra em meios aquosos com vários pH (1,2 e 6,8). Utilizando a análise da variação contínua de Job e os métodos de medida espectrofotométrica de Ardon, os valores das constantes de estabilidade da teofilina com o cetotifeno foram determinados em temperatura fixa $(37 \mathrm{oC})$ em vários $\mathrm{pH}$. As constantes de estabilidade, variando entre 5,66 e 9,92 derivaram-se a partir do delineamento de Ardon, indicando, comparativamente, que complexos estáveis se formaram como resultado da interação entre os fármacos. Entretanto, seguindo a interação da teofilina com o cetotifeno, as constantes de estabilidade foram $<1$, em pH gástrico $(1,2)$ e intestinal $(8,8)$. A administração concomitante de cetotifeno e teofilina poderia resultar na formação de complexo estável, o que reduz a atividade terapêutica de ambos os fármacos.

Uniterms: Constante de estabilidade. Método de Job. Método de Ardon. Cetotifeno. Teofilina.

\section{INTRODUCTION}

Ketotifen is a benzocycloheptathiophene derivative that has been shown to possess anti-histaminic and antianaphylactic properties (Martin, Romer, 1978). It has been demonstrated that it can block the in vitro release of mediators from rat peritoneal mast cells (Martin, Romer, 1978). The drug inhibits the release of histamine and leukotrienes from basophils and lung tissue, antagonises histamine at $\mathrm{H}_{1}$ receptors, inhibits calcium uptake, blocks the passive cutaneous anaphylactic reaction, reverses isoprenalineinduced beta-adrenoceptor tachyphylaxis, and inhibits both allergen-induced and drug-induced asthma (Craps,

*Correspondence: Razibul Habib. Department of Pharmacy, East West University. Dhaka - Bangladesh. E-mail: mrhjewel@gmail.com
Greenwood, Radielovic, 1978). A number of clinical trials of ketotifen have shown to have a beneficial effect in the treatment of asthma (Hoshino et al., 1998; Tinkelman et al., 1985) equivalent to that of disodium cromoglycate, which has an established place in the treatment of asthma (B.H./M.R.C.C.T., 1972; Clarke, May, 1980). Ketotifen, which is useful in the treatment of hay fever and asthma, has been found to inhibit anaphylactic histamine release from animal tissues (Martin et al., 1980). Theophylline, also known as dimethylxanthine, is a xanthine with bronchodilator properties and is used in the treatment of asthma and chronic obstructive pulmonary disease (COPD). Moreover, theophylline has been shown to have some anti-inflammatory activities, inhibiting the activity of CD4 lymphocytes in vitro and mediator release from mast cells (Salamzadeh et al., 2008). It also inhibits bronchoconstriction produced 
by exercise and challenge testing, and has been shown to have beneficial effects on the contraction of the diaphragm, an effect which may be particularly useful in patients with COPD (Kidney et al., 1990; Mak, 1997). Drug-drug interactions occur when one therapeutic agent either alters the concentration (pharmacokinetic interactions) or the biological effect (pharmacodynamic interactions) of another agent (Leucuta, Vlase, 2006). The clinical significance of a specific drug-drug interaction depends on the degree of accumulation of the substrate and the therapeutic window of the substrate (Bachmann, Lewis, 2005). The combination of theophylline and ketotifen is often used in respiratory tract infections and some have suggested that the combination is effective (Benjamin et al., 1994), while others have postulated that the combination may be embryotoxic, leading to growth retardation and morphological abnormalities (Bechter, Schön, 1988). The major goal of the present study was to elucidate the possible importance of drug-drug interactions (DDIs) as a contributing factor towards drug safety and finally to observe and determine the stability of the complexes which could be formed by the interaction of ketotifen fumarate with anhydrous theophylline in aqueous media at variable $\mathrm{pH}$. The values of the stability constants of theophylline with ketotifen were determined using Job's continuous-variation analysis and Ardon's spectrophotomeric measurement methods. However, following the interaction of theophylline with ketotifen, stability constants ranged between $0.4-2.0$ at $\mathrm{pH} 1.2$ and 4.12 at $\mathrm{pH}$. 6. The stability constant values indicate that co-administration of both drugs may reduce the pharmacological effect of the drugs.

\section{MATERIAL AND METHODS}

\section{Drugs and chemicals}

Ketotifen fumarate and anhydrous theophylline were obtained from Square Pharmaceuticals Ltd., Dhaka, Bangladesh as a gift and were used without further purification. Sodium dihydrogen orthophosphate and disodium hydrogen orthophosphate, used for the preparation of buffer solutions, were purchased from Merck, Germany. Potassium chloride, sodium hydroxide and potassium hydroxide were all of reagent grade.

\section{Equipment}

For these tests, we used a UV-Visible spectrometer (model no. UV-1600, Shimadzu, Japan), a pH meter (Mettler Toledo, Switzerland), an analytical balance (model number: AL 204-S/01) (Mettler Toledo, Switzerland), and a thermostatted water bath (Shimadzu, Japan). A Dunbuff metabolic shaking incubator (Nickel, Electrical Company, England) was used to shake the drug mixtures to attain equilibrium.

\section{Preparation of standard solutions}

Stock solutions of ketotifen fumarate $\left(1 \times 10^{-3} \mathrm{M}\right)$ and anhydrous theophylline $\left(1 \times 10^{-3} \mathrm{M}\right)$ prepared by dissolving them in distilled water. These stock solutions were diluted to the desired concentration $\left(1 \times 10^{-5} \mathrm{M}\right)$ in the buffer solutions to obtain the working standard solutions.

\section{Absorption spectrum analysis}

In the observation of the spectra, the absorption characteristics of ketotifen fumarate and theophylline and their 1:1,1:2, and 2:1 mixtures in the buffer solutions (Perrin, Dempsey, 1974; Mohiuddin et al., 2009) at $\mathrm{pH} 1.2$ and 6.8 were compared with those of each interacting species. The concentrations of the sample were kept at very dilute levels in each case and the measurements made using the UV-VIS spectrophotometer were taken at a constant temperature of the cell compartment and automatic recording unit. The stock solutions of the samples were diluted to the appropriate levels with the buffers $\left(1 \times 10^{-5} \mathrm{M}\right)$ at the desired $\mathrm{pH}$ and the spectra were recorded between $400-190 \mathrm{~nm}$. The spectra were compared with those of the pure samples in each case.

\section{Job's spectrophotometric method}

According to Job's method (Job, 1971) a series of solutions were prepared in which the analytical concentration of one reactant (usually the cation) was held constant while that of the other was varied. The absorbance of a series of ketotifen fumarate with theophylline in different molar ratios $(1: 9,2: 8,3: 7,4: 6,5: 5,6: 4,7: 3,8: 2,9: 1)$ was measured by keeping the total molar concentration constant. The observed absorbance of the mixtures at various molar fractions was subtracted from the sum of the values for the free drugs (ketotifen fumarate and anhydrous theophylline). The absorbance difference (D) was then plotted against the molar fractions of the drug in the mixtures. If the formation constant is reasonably favourable, two straight lines with different slopes that intersect at a molar ratio that corresponds to the ratio of drugs in the complex are obtained.

\section{Ardon's spectrometric method}

The anhydrous theophylline concentration was kept fixed $\left(2 \times 10^{-4}\right)$ while the ketotifen concentrations were 
varied. The absorbance of free drug solutions and those of mixtures were measured at $300 \mathrm{~nm}$ at different $\mathrm{pH}$. From Ardon's equation (Ardon, 1971) the values of $1 /\left(D-C_{\varepsilon A}\right)$ versus $1 /$ drug were plotted and the values of the stability constants were calculated from the intercept/slope of the straight lines. In the above equation $\mathrm{D}$ is the absorbance of the mixture, $\mathrm{C}$ is the molar concentration of ketotifen, and $\varepsilon \mathrm{A}$ is the molar extinction coefficient of the complex.

\section{RESULTS AND DISCUSSION}

By spectral observation analysis, both of the studied drugs showed absorption in the UV-VIS range. The molecular species of ketotifen fumarate and theophylline, when observed separately, showed some changes in the absorption characteristics of the drug molecules, including shifts in the absorption maxima. The initial detection of the complexation of ketotifen fumarate with theophylline was obtained from the spectra of the pure compounds as well as their $1: 1,1: 2$, and 2:1 mixtures in buffer solutions at $\mathrm{pH} 1.2$ and 6.8 at a fixed concentration $\left(1 \times 10^{-5} \mathrm{M}\right)$. It is clear that each compound has a unique molecular structure or electronic configuration which is responsible for the absorption of light in the ultraviolet or visible range. For this reason, the UV-spectrum of any pure compound will be unique and totally different from another compound or a complex of that compound with another compound. The spectrum of ketotifen fumarate alone at different $\mathrm{pH}$ showed a sharp absorption maximum at $300 \mathrm{~nm}$. When theophylline was mixed with ketotifen in a $2: 1$ ratio, the intensity of the peak of ketotifen changed remarkably (decreased absorbance), i.e. the absorption characteristics were altered due to the interaction, but the position of the compound did not shift. The UV spectra of ketotifen at $\mathrm{pH}$ 1.2 and 6.8 and the $1: 1,1: 2$, and $2: 1$ mixtures of ketotifen fumarate with theophylline at the same $\mathrm{pH}$ are shown in Figure 4 and Figure 5. The curves obtained by Job's method show breaks at different molar concentrations for both drugs. It was found that the curves obtained at $\mathrm{pH} 6.8$ were somewhat flat compared to those at $\mathrm{pH}$ 1.2. On the other hand, the kinetics of the interaction between ketotifen fumarate and theophylline anhydrous were slow at $\mathrm{pH} 1.2$ (Figure 1). The continuous variation plot provides information on the relative affinities of the complexes and depends on the intrinsic spectral characteristics of each complex.

Ardon's plots have been used to evaluate stability constants. It has been observed that when values of $1 /\left(\mathrm{D}-\mathrm{C}_{\varepsilon \mathrm{A}}\right)$ are plotted against 1/drug (Figure 2), straight lines are obtained following Ardon's equation. The values of the stability constants at different $\mathrm{pH}$ levels are shown in

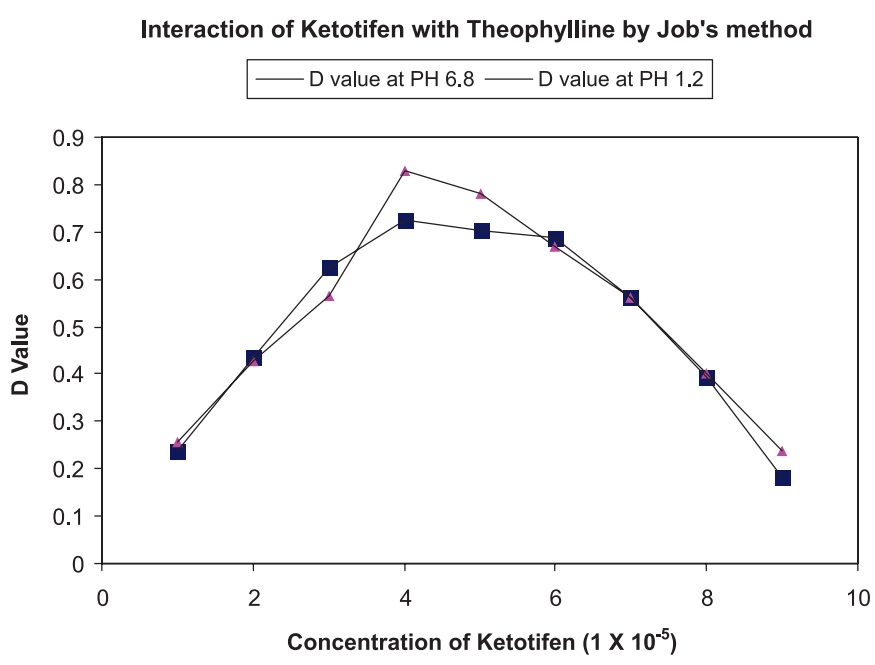

FIGURE 1 - Job's plot for the complexation of ketotifen with theophylline at $300 \mathrm{~nm}$.

TABLE I - Absorbance of ketotifen at different pH (using Job's method)

\begin{tabular}{ccc}
\hline \multirow{2}{*}{$\begin{array}{c}\text { Conc. of Ketotifen } \\
(\mathrm{M})\end{array}$} & \multicolumn{2}{c}{ Absorbance (D Value) } \\
\cline { 2 - 3 } $1 \times 11^{0-5}$ & 0.256 & $\mathrm{pH} 6.8$ \\
\hline $2 \times 10^{-5}$ & 0.426 & 0.288 \\
$3 \times 10^{-5}$ & 0.564 & 0.391 \\
$4 \times 10^{-5}$ & 0.831 & 0.454 \\
$5 \times 10^{-5}$ & 0.78 & 0.506 \\
$6 \times 10^{-5}$ & 0.67 & 0.514 \\
$7 \times 10^{-5}$ & 0.562 & 0.516 \\
$8 \times 10^{-5}$ & 0.402 & 0.445 \\
$9 \times 10^{-5}$ & 0.237 & 0.512 \\
\hline
\end{tabular}

Table III and Table V. Very low stability constant numerical values (between negative values and 1) mean that the formation of the complex due to an interaction between the drugs is readily dissociated (Table V), yielding essentially all drugs in ionic form at low $\mathrm{pH}$ as in the stomach (about $\mathrm{pH} 2$ to 3 ) to as high as physiological ( $\mathrm{pH} 7.4$, the $\mathrm{pH}$ of extracellular body fluids such as serum and lymph) (Landy et al., 1999).

The numerical values of the resulting stability constants were 9.92 at $\mathrm{pH} 1.2$ and 5.66 at $\mathrm{pH} 6.8$ when complexation occurred with ketotifen and theophylline (Table III). These values indicate a good interaction between ketotifen and theophylline. It can be assumed that these two drugs can be safely administered orally at the same time. Following Ardon's method, when theophylline is considered as the parent drug and interacts with 
TABLE II - Absorbance of ketotifen at different pH (using Ardon's method, when the concentration of theophylline is constant)

\begin{tabular}{ccc}
\hline \multirow{2}{*}{$1 / \mathrm{D} \times 10^{-5}$} & \multicolumn{2}{c}{$1 /\left(\mathrm{D}-\mathrm{C}_{\varepsilon \mathrm{A}}\right)$} \\
\cline { 2 - 3 } & $\mathrm{pH} 1.2$ & $\mathrm{pH} 6.8$ \\
\hline 1.000 & 38.5 & 33.3 \\
0.500 & 32.3 & 4.0 \\
0.330 & 8.4 & 4.7 \\
0.250 & 4.5 & 2.3 \\
0.200 & 2.9 & 1.8 \\
0.167 & 2.0 & 1.7 \\
0.143 & 1.5 & 1.4 \\
\hline
\end{tabular}

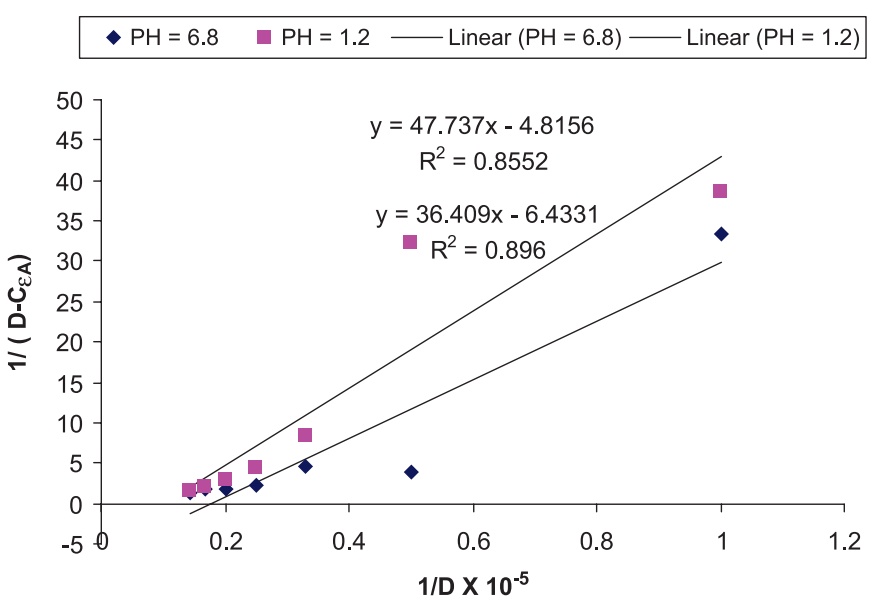

FIGURE 2 - Ardon's plot for the complexation of ketotifen with theophylline at $300 \mathrm{~nm}$.

TABLE III - Stability constant of ketotifen with theophylline at different $\mathrm{pH}$

\begin{tabular}{lcc}
\hline System & $\mathrm{pH}$ & $\begin{array}{c}\text { Stability } \\
\text { constant }\end{array}$ \\
\hline $\begin{array}{l}\text { Interaction of ketotifen with } \\
\text { theophylline }\end{array}$ & 1.2 & 9.92 \\
\hline
\end{tabular}

ketotifen, a lower stability constant was found, indicating the ready solubility of both drugs and a minimal drug-drug interaction (Figure 3).

\section{CONCLUSION}

The interaction of ketotifen with theophylline de-
TABLE IV - Absorbance of ketotifen at different pH (using Ardon's method, when the concentration of ketotifen is constant)

\begin{tabular}{ccc}
\hline \multirow{2}{*}{$1 / \mathrm{D} \times 10^{-5}$} & \multicolumn{2}{c}{$1 /\left(\mathrm{D}_{-} \mathrm{C}_{\varepsilon \mathrm{A}}\right)$} \\
\cline { 2 - 3 } & $\mathrm{pH} 1.2$ & $\mathrm{pH} 6.8$ \\
\hline 1 & 3.226 & 2.577 \\
0.500 & 3.125 & 1.724 \\
0.333 & 3.300 & 1.754 \\
0.250 & 3.367 & 1.698 \\
0.200 & 3.497 & 1.761 \\
0.167 & 3.546 & 1.715 \\
0.143 & 3.145 & 1.698 \\
\hline
\end{tabular}

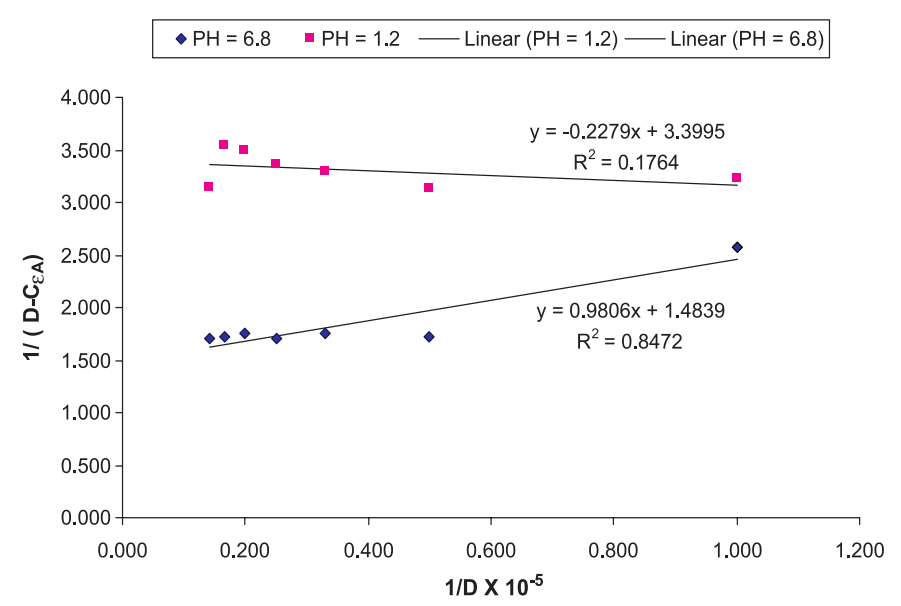

FIGURE 3 - Ardon's plot for the complexation of theophylline with ketotifen at $300 \mathrm{~nm}$.

TABLE V - Stability constant of theophylline with ketotifen at different $\mathrm{pH}$

\begin{tabular}{lcc}
\hline System & $\mathrm{pH}$ & $\begin{array}{c}\text { Stability } \\
\text { constant } \\
\left(1 \times 10^{-2}\right)\end{array}$ \\
\hline $\begin{array}{l}\text { Interaction of theophylline } \\
\text { with ketotifen }\end{array}$ & 1.2 & 6.70 \\
\hline
\end{tabular}

creases the free drug concentration of both drugs, which can result in decreased availability of the drugs at their receptors. Ultimately, one or both drugs may show diminished pharmacological activity. Therefore, caution should be exercised during the administration of both drugs, pending in vivo experiments to determine the implications of our findings. 

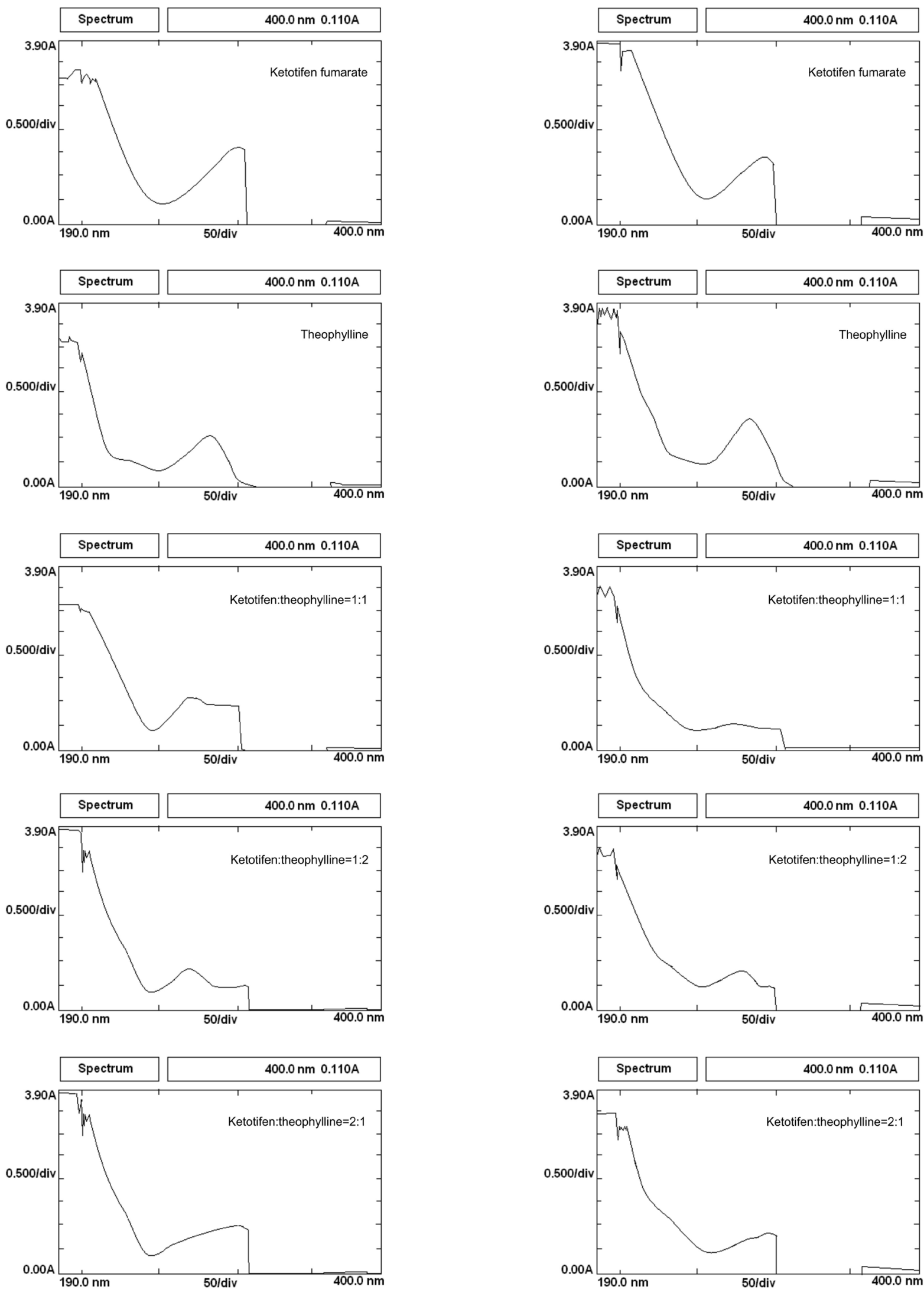

FIGURE 4 - Spectral studies of ketotifen fumarate and theophylline at $\mathrm{pH}$ 1.2. $\mathbf{X}$ axis: UV range; $\mathbf{Y}$ axis: absorbance.

FIGURE 5 - Spectral studies of ketotifen fumarate and theophylline at pH $6.8 \mathbf{X}$ axis: UV range; $\mathbf{Y}$ axis: absorbance. 


\section{REFERENCES}

ARDON, M. Oxidation of ethanol by ceric perchlorate. $J$. Chem. Soc., [Online]. p.1811-1815, 1957. Available at: $<$ http: // pubs.rsc.org/en/content/articlelanding/ 1957/jr/jr 9570001811>. Accessed on: 02 aug. 2011.

BACHMANN, K.; LEWIS, J.D. Predicting inhibitory drug-drug interactions and evaluating drug interaction reports using inhibition constants. Ann. Pharmacother., v.39, p.10641072, 2005.

BECHTER, R.; SCHÖN, H. Use of the whole-embryo culture system in drug safety assessment. Toxicol. in vitro, v.2, p.195-203, 1988.

BENJAMIN, V.; JACOB, A.; HAGIT, M.; MAYA, L.; ITZHAK, V. Administration of half-dose theophylline together with ketotifen to asthmatic children-a double-blind, placebocontrolled study. J. Asthma, v.31, p.27-34, 1994.

BROMPTON HOSPITAL. Medical Research Council Collaborative Trial. Long-term study of disodium cromoglycate in treatment of severe extrinsic or intrinsic bronchial asthma in adults. Br. Med. J., v.4, p.383-388, 1972.

CHURCH, K.M.; GRADIDGE, C.F. Inhibition of histamine release from human lung in vitro by antihistamines and related drugs. Br. J. Pharm., v.69, p.663-667, 1980.

CLARKE, C.W.; MAY, C.S. A comparison of the efficacy of ketotifen (HC 20-511) with sodium cromoglycate (SCG) in skin test positive asthma. Br. J. Clin. Pharmacol., v.10, p.473-476, 1980.

CRAPS, L.; GREENWOOD, C.; RADIELOVIC, P. Clinical investigation of agents with prophylactic anti-allergic effects in bronchial asthma. Clin. Allergy, v.8, p.373-382, 1978.

HOSHINO, M.; NAKAMURA, Y.; SIM, J.J.; TOMIOKA, H. A comparative study of the effects of ketotifen, disodium cromoglycate, and beclomethasone dipropionate on bronchial mucosa and asthma symptoms in patients with atopic asthma. Respir. Med., v.92, p.942-950, 1998.
JOB, P. Job's method of continuous variation. Ann. Chim., v.9, p.113-203, 1928.

KIDNEY, J.; DOMINGUEZ, M.; TAYLOR, P.M.; ROSE, M.; CHUNG, K.F.; BARNES, P.J. Immunomodulation by theophylline in asthma. Demonstration by withdrawal of therapy. Am. J. Respir. Crit. Care Med., v.151, p.19071914, 1995.

LEUCUTA, S.E.; VLASE, L. Pharmacokinetics and metabolic drug interactions. Curr. Clin. Pharmacol., v.1, p.5-20, 2006.

MAK, V. Chest medicine on-line, chronic obstructive pulmonary disease (COPD): the UK perspective. Available at: $<$ http:// www.prioiry.com/cmol/ copd.htm>. Accessed on: 19 May 2007.

MARTIN, U.; ROMER, E. Ketotifen: a histamine release inhibitor. Monogr. Allergy, v.12, p.145-149, 1977.

MOHIUDDIN, M.; AZAM, Z.; AMRAN S.; HOSSAIN, M.A. In vitro study on the interaction of caffeine with gliclazide and metformin in the aqueous media. J. Pharmacol. Toxicol., v.4, p.194-204, 2009.

PERRIN, D.D.; DEMPSEY, B., Buffer for $\mathrm{pH}$ and metal ion control. London: Chapman and Hall, 1974. p.211-216.

SALAMZADEH, J.; DADASHZADEH, S.; HABIBI, M.; ESTIFAIE, S. Serum and saliva theophylline levels in adult outpatients with asthma and chronic obstructive pulmonary disease (COPD): a cross-sectional study. IJPR, v.7, p.83$87,2008$.

TINKELMAN, D.G.; MOSS, B.A.; BUKANTZ, S.C.; SHEFFER, A.L.; DOBKEN, J.H.; CHODOSH, S.; COHEN, B.M.; ROSENTHAL, R.R.; RAPPAPORT, I.; BUCKLEY, C.E.; CHUSID, E.I.; DEUTSCH, A.J.; SETTIPANE, G.A.; BURNS, R.B.P. A multicenter trial of the prophylactic effect of ketotifen, theophylline, and placebo in atopic asthma. $J$. Allergy Clin. Immunol., v.76, p.487-497, 1985.

Received for publication on $2^{\text {nd }}$ February 2011 Accepted for publication on $15^{\text {th }}$ March 2012 